\title{
Assessment of channeling bias among initiators of glucose-lowering drugs: A UK cohort study [Corrigendum]
}

Ankarfeldt MZ, Thorsted BL, Groenwold RHH, et al. Clin Epidemiol. 2017;9:19-30.

On page 23, Figure 1 Notes section was marked incorrectly. The correct Notes should read as follows:

Figure I Propensity score over time for GLP-I versus basal insulin initiators. Notes: Blue: insulin, red: GLP-I.

Abbreviation: GLP-I, glucagon-like peptide-I analogs.

On page 24, Figure 2 Notes section was marked incorrectly. The correct Notes should read as follows:

Figure 2 Propensity score over time for DPP-4i versus sulfonylurea initiators. Notes: Blue: sulfonylurea, red: DPP-4i.

Abbreviation: DPP-4i, dipeptidyl peptidase-4 inhibitors.
On Page 3 of Supplementary materials, Figure S2 caption was shown incorrectly. The correct caption should read as follows:

Figure S2 Histograms of propensity score over time. Intention-to-treat and perprotocol cohorts of all identified initiators of GLP-I and insulin, and DPP-4i and sulfonylurea, respectively. Blue: insulin and sulfonylurea initiators, respectively. Red: GLP-I and DPP-4i initiators, respectively.

Despite the above corrections, the interpretation of these figures in the published proof and the Supplementary materials was correct.
Clinical Epidemiology

\section{Publish your work in this journal}

Clinical Epidemiology is an international, peer-reviewed, open access, online journal focusing on disease and drug epidemiology, identification of risk factors and screening procedures to develop optimal preventative initiatives and programs. Specific topics include: diagnosis, prognosis, treatment, screening, prevention, risk factor modification,

\section{Dovepress}

systematic reviews, risk and safety of medical interventions, epidemiology and biostatistical methods, and evaluation of guidelines, translational medicine, health policies and economic evaluations. The manuscript management system is completely online and includes a very quick and fair peer-review system, which is all easy to use. 